\title{
COUNTRY OF ORIGIN, BRAND IMAGE AND HIGH INVOLVEMENT PRODUCT TOWARDS CUSTOMER PURCHASE INTENTION: EMPIRICAL EVIDENCE OF EAST MALAYSIAN CONSUMER
}

\author{
Mohd Amirul Adenan ${ }^{1 *}$, Jati Kasuma Ali ${ }^{2}$, Dayang Humida Abang Abdul Rahman ${ }^{3}$ \\ ${ }^{1}$ Hull University Business School, University of Hull, United Kingdom \\ ${ }^{23}$ Universiti Teknologi MARA Malaysia, Malaysia \\ *Corresponding author; Email: amiruladenan91@ gmail.com
}

\begin{abstract}
This research strives to understand East Malaysian consumers' purchase intention when being exposed to the effects of brand image and country of origin (COO) image in the case of high involvement products. Self-administered questionnaires were collected from 225 consumers in East Malaysia. The result of this study shows that East Malaysian consumers' put a large importance on brand and country of origin image in high involvement products as they are more involved in information searching and decision making when purchases these products. Implication and future research also discussed.
\end{abstract}

Keywords: East Malaysian consumers, country of origin (COO), brand image, high involvement products, purchase intention.

\section{Introduction}

Julian and Ahmed (2009) explain that Malaysian economy has always been relying on the international trade where product imports are one of the main contributions to the development of its economy. These product imports provide Malaysia with capital and consumer goods as well as semi-finished products for Malaysian producers in a competitive pricing. Figure 1 shows a report by the Department of Statistics Malaysia of the trade imports in February 2016 with 49.4 billion of value increased to 63.1 billion in the February of 2017. The report also implied that the increase in competition of the consumer products are one of the factors that leads to the increase of the trade imports. To gain a competitive advantage, international marketers have often searching for the right strategies to help them in leveraging their brands. COO image and brand image are among the important elements that marketers would focus upon in building their strategy.

As mentioned earlier, the increase in international trade saw to the high availability of international products in different countries and whether these products are accepted or not by the consumers in various parts of the world is of a paramount importance. Therefore, the firms with a global presence must understand how brands and country association works and how it impacts their products acceptance of the global consumers that leads to the study of country of origin $(\mathrm{COO})$.

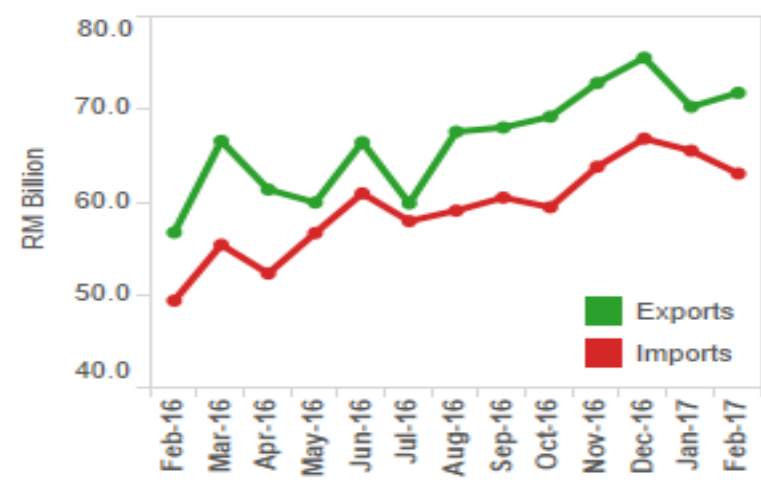

Figure 1.

Source: Department of Statistics Malaysia, 2017

Due to the rapid growth of international business, increased presence of multinational companies, joint ventures between large firms and international marketing and operations, it has become imperative for international firms to understand how country of origin works as the market becomes more competitive due to the availability of various international products within the country. Consumers now have a wide selection of products with different brands to choose from and firms have to figure out what are the cues that make consumers choose their brands instead of the other. $\mathrm{COO}$ and brand image are among the most important cues that influence consumers' purchase intention. Throughout the years, many researches have been done regarding this topic to assist international marketers and businesses alike in leveraging their brands within the global market. 
However, there are certain arguments made by past researches on the effects of level of product involvement towards $\mathrm{COO}$ and consumers' purchase intention. One such argument is the effect of $\mathrm{COO}$ that has a little influence on consumer behaviour in a high level of product involvement. This is because the consumers tend to search for other visible information regarding the brand (Verlegh, Steenkamp, \& Meulenberg, 2005; Maheswaran, 1994). Shahzad (2014) argued that the effects are the opposite where COO has a higher effect in high involvement situations as consumers are more involved in information searching. Tabassi, Esmaeilzadeh and Sambasivan (2013) suggests that future study should include other product cues such as brand image and $\mathrm{COO}$ cues to further understand the impact towards consumer purchase intention in Malaysia. This study is also justified by Shahzad (2014) as it is concluded that a further research can be done is the effect of brand image, to find out whether $\mathrm{COO}$ supports the brand or the brand image itself supports the COO. Thus, this study would like to clarify this argument in the case of East Malaysian consumers. Therefore, the objectives of this paper to investigate relationship of brand image and $\mathrm{COO}$ and the effect of high level of product involvement as a moderator towards East Malaysian consumers' purchase intention.

\section{Country of Origin (COO) Image}

Throughout the years, country-image becomes the main topic as researchers argue the assessment of product made by the consumers are tied to the origin of the product in a certain country where different countries resulted in different attitudes by the consumers. Thus, the terms country equity and product country image (Shimp, Samie, \& Madden, 1993) are included in the study of $\mathrm{COO}$ where both are related but with a small difference. Chen (2009) clarifies $\mathrm{COO}$ image as the study of the consumer's behaviour when subjected to different $\mathrm{COO}$ cues which will then develops their perception and finally affecting their purchase decisions. These cues, consist of the overall image of country, the cognitive feeling of the product's overall quality and the competence and reputation of the country in a certain product category Said, Hassan and Musa (2011). For example, Switzerland is known as the producer of high quality watches and has the overall country image of being reliable and competent.

Understanding the effect of $\mathrm{COO}$ towards consumer behaviour is a critical issue in the marketing world which explains the various researches being made by scholars in the past years. Ahmed, Johnson,
Ling, Fang, and Hui (2002), found that a direct influence of $\mathrm{COO}$ on the perceptions of consumers towards product attributes which then affects their product evaluations. Due to the large information being supplied towards consumers regarding the brand, they use this information to influence their buying decisions, which includes the information of COO. In relations to this, Obermiller and Spangenberg (1989) that explain the effect of $\mathrm{COO}$ on product evaluations based on the cognitive, affective and normative processing of the COO cue. On top of that the cognitive process depends on the existence of other information where consumers will refer to the $\mathrm{COO}$ information when no other indicators are available. When other information such as performance and functions of the product are available, consumers would use them instead of COO information as it is viewed as a better indicator of the product (Obermiller \& Spangenberg, 1989).

In fact, Obermiller and Spangenberg (1989) refer the other two processes of affective and normative depend less on the external cues and more towards the presence and clarity of the country origin label that act as the trigger. An affective process depends on the response consumers made towards country stereotype which outweigh other cues of COO. In an affective processing, marketers should focus on bringing the positive aspect of the country and to obscure the $\mathrm{COO}$ cues if the country stereotype is not favourable to them. In a normative processing, the $\mathrm{COO}$ cues are affected by the consumers' behaviour towards their normative pressure which relates to the study of ethnocentricity of the country. For example, "Buy American" theme used by marketers to pressure the consumers to support the country's product even if there are other countries that are superior in the product type or products from a specific country are boycotted due to political reasons. Marketers that face these normative blocks can either change the consumers' social norm; slowly change the consumers' motivation towards the norms or using the simplest way of obscuring the $\mathrm{COO}$ information of the product.

\section{Brand Image}

Brand can be defined as a name, design or symbol or combination of them with the purpose of identifying the goods and services that the firm is selling and to differentiate them with those of the competitors (Kotler, 1991). The study of branding has become extensively important over the years. The highly competitive marketplace nowadays has pushed companies to have deeper understanding in con- 
sumers' behavior and to educate consumers about their brand to develop a solid marketing strategy that would enable them to compete in their respective industry. By referring to the various earlier literatures, Keller (1993) came up with the definition of brand image as the perceptions by the consumers towards a brand as reflected by the brand associations that they stored in their memory. Brand image is part of the component of the brand knowledge and it has been studied since the early $20^{\text {th }}$ century as it is an integral part in building brand equity. The latest literature by Lee, James and Kim (2014) reconceptualise the definition of brand image as "The sum of a customer's perceptions about a brand generated by the interaction of the cognitive, affective, and evaluative processes in a customer's mind'. Thus, with the new concept of brand image, a more effective measurement of construct on the application of brand image is possible as the concept is now defined consistently.

Consumers buying behavior towards a product depends heavily on the brand association's favorability and strength (Shimp, 2010). The associations made by consumers may vary depending on the favorability of their evaluation, that is, whether the brand possess the attributes and benefits that would be able to fulfill their needs and wants. Strength of the connection between the nodes and the links as stated in the associative network model is also one of the integral parts that determine how a consumer would behave towards a certain product or service. Keller (2001) stated that a desirable brand association would not matter if it is not strong enough to make customers recall and associate it with the brand. The strength depends on how much information that a person process regarding the brand and the quality of the information that the person receives. Take the brand Apple as an example. The brand itself is known for its fast operating system and will not be affected by a virus that would disrupt the system. This gives the brand a favorable association as consumers would benefit from the product's attributes (fast and virusfree operating system) which would lead to a favorable attitude towards the brand. The benefit that customers would obtain from the brand would strengthen its association as they will remember the attributes, benefits and attitudes that they have towards they brand. This example, along with other advantages that the brand possesses would explain their many loyal customers even with the premium price that they have towards most of their products. Therefore, it is important for marketers to understand how brand image would affect a consumer' purchase decisions as they would be able to leverage their brands to create a stronger and positive associations in consumers' mind.

\section{The Effects of Brand Image and Coo Image towards Purchase Decision}

Consumers in the market are known to link a brand with its home country even without the presence of country of origin. But, does country of origin image helps to leverage the brand image of a product or does country of origin function the same as other external cues? There are many researches been made regarding this issue and one such research is by Pappu, Quester, \& Cooksey (2006) where they emphasise that $\mathrm{COO}$ only serve as a secondary association to the product the same as other external cues does. The research explained that consumers would automatically relate a brand with its home country even without the presence of information regarding the country of origin. The brand itself, however, could use various other external cues or entities to create secondary associations. In a literature by Keller (1993), it is explained that brand image or the brand itself can be linked to many different entities such as people, places, events and country of origin information is one of the entity. These external entities would then create a positive product attributes, benefits and overall consumer attitude towards a product which creates a strong and favourable association that leads to purchase decisions.

However, Kouba (2008) argued that COO is used in helping consumers to recognize the brand image of the product where the concept of umbrella brand image was emphasised. Kouba (2008) explains the term as the situation where the brand image perception of a product is dependent on the country image perception contained in the $\mathrm{COO}$ information. A product's brand image has a high possibility to be affected if it is a famous brand produced in a wellknown country compared to a product where the country it is being produced is not known or famous for any attributes that a consumer can relate. This would explain the affective processing of the $\mathrm{COO}$ in the earlier literature where consumers use country stereotypes to leverage the brand image of a product. This issue is supported by earlier research by Scott and Keith (2005) and Hui and Zhou (2002) where they explained that consumers usually would recall and relate the information of the brand and its country of origin to structure the brand image in their mind. This process would finally lead to the deduction of product evaluation and purchase intention of the product. International marketers are known in using the umbrella brand image in their branding strategy as it helps them to use the brand's country stereotype to their advantage. The issues discussed in this literature 
leads to the current study to identify the importance of both brand image and $\mathrm{COO}$ image towards consumers' purchase decisions as it is important for marketers to understand how they can leverage $\mathrm{COO}$ information in their strategy and create the ideal brand image that they desire.

\section{High Involvement Products and Its Effect on COO Image}

Consumers buy products to fulfil their want and needs, to motivate and improve their personal image. However, there are differences in the level of involvement that they make towards various products that they have bought. According to Saeed et al. (2013), involvement is defined as consumers' level of comprehension and recollection towards a certain product and it is divided into category of purchasing, advertising and product involvement. For the purpose of the current study, product involvement will be given a focus in the literature. Zdravkovic (2013) implies that the level of product involvement depends on the extent that consumers are involved and interested towards the product. This means that the more involved and interested consumers are in a product, the higher the level of product involvement. Previous researchers such as Verlegh et al. (2005) and Tabassi et al. (2013) have studied the effects of levels of product involvement towards COO image. Verlegh et al. (2005) stated that in the case of high level of product involvement, consumers would be more involved in information searching and therefore, would rely less on $\mathrm{COO}$ information for their product evaluation. This statement implies that when purchasing an expensive product, consumers tend to search for much conspicuous information such as the brand image or the price of the product rather than the country where it is originated from. However, Shahzad (2014) argued that the opposite effect would occur where in a high product involvement, $\mathrm{COO}$ will have a large influence in purchase decision as consumers would find more information regarding the product including COO. The research by Tabassi et al. (2013) would support this point where they have indicated that in a low product involvement, consumers give less effort in their purchase decision and are already familiar with the product and thus, would not rely on its $\mathrm{COO}$ information. Tabassi et al. (2013) also explained that due to the different level of information being made available in different countries, the effects of high and low level of product involvement may also be different in developed or developing country.

\section{The Theory of Planned Behaviour}

The current research will study about consumers purchase decision where according to Dodds, Monroe, and Grewal (1991), purchase decision refers to possibility that a consumer would purchase the product being focused on. There are various theories being used to understand a consumer's purchase theories. In this literature, the theory of planned behaviour will be discussed to understand how and what drives a consumer to behave as they do. Ajzen (1991) explains the theory of planned behaviour (TPB) is driven by the person's intention to execute certain behaviour and presumed to gain the motivational factors that affect the behaviour which shows how much effort a person is willing to give to perform that behaviour.

This intention is determined by three underlying considerations or beliefs (Ajzen, 2015). The first consideration is "behavioural belief" which defined as the person's perception towards the consequences of executing the behaviour, be it negative or positive and these beliefs that are already stored in that person's memory will lead to an "attitude towards the behaviour". A normative belief is the person's perception of how an important referent groups would expect from that person and his or her own motivation to comply with the referent. The normative belief that is in the person's memory will create a perceived social pressure or subjective norm to perform the behaviour. Ajzen (2015) further explains that the last consideration is the control belief which refers to the perceived availability of factors that influence the person's ability to execute the intended behaviour. With the presence of these factors that will help in performing or stopping the behaviour, it would then lead to perceived behavioural control or self-efficacy in relation to the intended behaviour. Therefore, it can be concluded that a favourable attitude and subjective norm in undertaking the behaviour and a stronger perceived control would increase the likelihood that the person would perform the behaviour.

In terms of the current study, the consumers' buying behaviour is affected by $\mathrm{COO}$ image and brand image of the product. The effect of consumer's purchase intention of this study will be based on Figure 2 of Ajzen's (1991) theory of planned behaviour. The $\mathrm{COO}$ cues that consumers receive or the brand image of the product would create an attitude towards the "behavioural belief'. For example, a Swatch product depicts a high-quality watch due its country reputation and brand image, and thus, create a positive attitude towards the product and that consumers 
would perceived that they would gain a favourable "consequences" in buying the product. The brand of the product that depicts a positive image would improve the consumers' social standing which would help in improving their subjective norm. Finally, with the availability of enough information regarding a product's $\mathrm{COO}$ and brand image would give them the perceived behavioural control which then leads to their buying decisions. Therefore, understanding the consumer's behaviour is an important part for international marketers to better leverage $\mathrm{COO}$ and brand image in their marketing strategy.

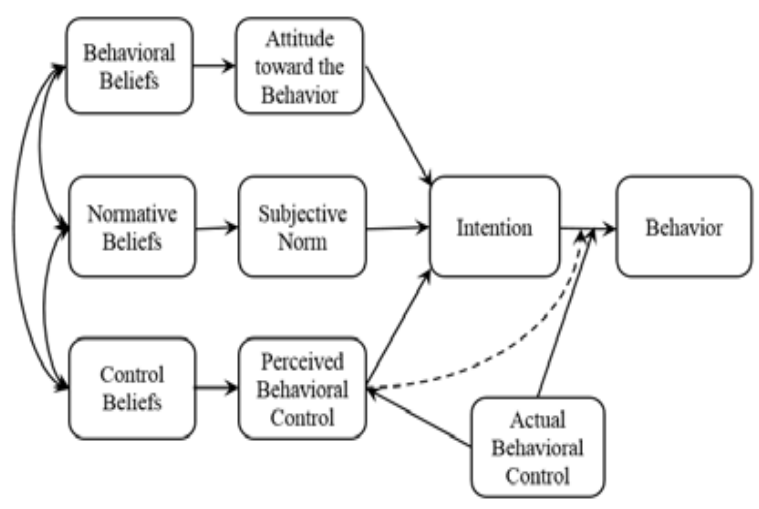

Figure 2. The theory of planned behaviour

Source: Ajzen, 2015

\section{Conceptual Framework}

Based on the literatures discussed earlier, a conceptual framework was developed for this study as shown on Figure 3.

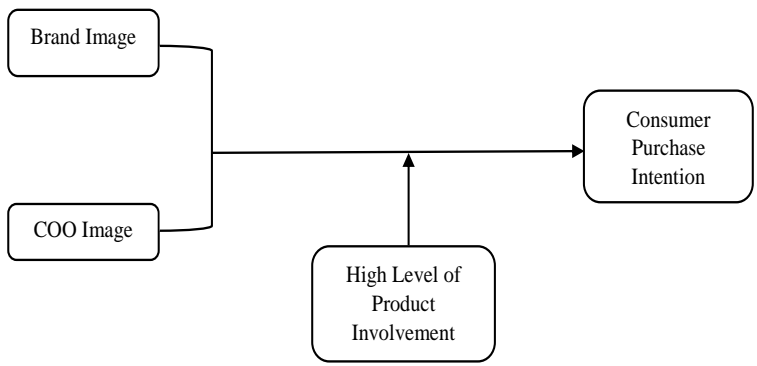

Figure 3. Conceptual framework: Country of origin, brand image and high involvement product towards customer purchase intention

\section{Hypothesis Development}

The following hypotheses were derived for the study.

$H_{l}$ : There is a positive relationship between $\mathrm{COO}$ image, brand image and purchase intention.
$\mathrm{H}_{2}$ : COO image gives a greater influence towards consumers' purchase intention compared to brand image.

$\mathrm{H}_{3}$ : The influence of $\mathrm{COO}$ image and brand image on purchase intention is moderated by high level of involvement products.

\section{Research Method}

Self-administered questionnaire was distributed, and 225 completed and usable questionnaires were collected among East Malaysian consumers. Descriptive analysis, correlation analysis and regression analysis were used to test the data obtained from the questionnaires obtained. The items for measuring the variables of the study was adopted from previous researches where the scales that measure the variables COO image and high level of product involvement were taken from the research by Zain and Yasin (1997). The measurement of scales of brand image were obtained from the research done by Tong and Howley (2009), Lai, Chiu, Yang and Pai (2010) and Keller (1993). According to Dodds et al. (1991), consumer's purchase decision is referred to the disposition of a consumer to purchase a product. Therefore, the measurement of scales from the research by Dodds et al. (1991) are used to measure the variable of purchase decision as it is in line with the variable of the current study. The research by Hanzaee and Khosrozadeh (2011) will also be adopted for the measurement of purchase decision. To obtain the first objective of the study and prove the first hypothesis suggested, correlation analysis was used to identify the relationship strength and congruity between the variables of COO image, brand image and purchase decision. In identifying which independent variables of COO image and brand image gives off a greater effect on purchase decision (dependent variable), regression analysis was used where each of the effects of the independent variables was tested towards the dependent variable. Finally, to answer the last objective and hypothesis suggested earlier, a Baron and Kenny moderation analysis was used to investigate the effect of high product involvement (moderator) with the relationship of COO image and brand image (independent variables) towards purchase decision (dependent variable).

\section{Results and Discussion}

The Table 1 shows the demographic details of the respondents of the study. 
Table 1

Demographic Data of the Respondents

\begin{tabular}{lcc}
\hline Category & $\begin{array}{c}\text { Frequency } \\
\text { Percentage of } \\
\text { Total (\%) }\end{array}$ \\
\hline Gender & 155 & 60.8 \\
Male & 100 & 39.2 \\
Female & & \\
Age & 37 & 14.5 \\
21 to 30 & 52 & 20.4 \\
31 to 40 & 58 & 22.7 \\
41 to 50 & 108 & 42.4 \\
51 and above & & \\
Education Levels & 65 & 25.5 \\
Diploma & 88 & 34.5 \\
Undergraduate & 97 & 38.0 \\
Postgraduate & 5 & 2.0 \\
Doctorate & & \\
Income Levels per & 29 & 11.4 \\
Month & 51 & 20.0 \\
2 000 or less & 65 & 25.5 \\
2 001 to 4 000 & 110 & 43.1 \\
4 001 to 6 000 & & \\
6 001 or more & & \\
\hline
\end{tabular}

\section{Research Objective 1: To investigate the relationship of COO image and brand image towards East Malaysian's consumers' purchase intention.}

The results show that all the values are positive, and all of the variables has medium to strong relationship based on guidelines given by Cohen (1988), as cited by Pallant (2013), where the value of 0.10 to 0.29 shows a small relationship, 0.30 to 0.49 shows a medium relationship and a large relationship is shown when the values is at 0.50 to 1.0. The positive relationship of these variables shows that as the value of one variable increases, the other would increase as well.

Table 2.

Correlation Matrix

\begin{tabular}{lccc}
\hline & $\begin{array}{c}\text { COO } \\
\text { Image }\end{array}$ & $\begin{array}{c}\text { Brand } \\
\text { Image }\end{array}$ & $\begin{array}{c}\text { Purchase } \\
\text { Intention }\end{array}$ \\
\hline COO Image & 1 & & \\
Brand Image & 0.531 & 1 & \\
Purchase Intention & 0.508 & 0.480 & 1 \\
\hline
\end{tabular}

Based on the results obtained, it is found that $\mathrm{COO}$ image has a strong and positive relationship with purchase intention. These findings were supported by Obermiller and Spangenberg (1989) where they explained that in an affective process, consumers use the presence of $\mathrm{COO}$ label that act as a catalyst in consumer purchase behaviour. A product that has a good COO image tends to influence consumers more compared with the ones having a bad COO image. As an example, consumers have a high regard on Swatch brands as Switzerland is a country known for producing quality watches. The relationship between brand image and purchase intention also has the same effect as COO image which proves the statement of Shimp (2010) where consumer's behaviour depends on the brand association's strength and favourability that consumers stored in their memory. The stronger and more favourable image the brand gives off, the more likely it will affect consumer's product evaluations. Thus, the first hypothesis of this study is accepted, and the first objective of the study was also achieved.

\section{Research Objective 2: To study the degree of impact between brand image and $\mathrm{COO}$ image towards purchase intention of consumers in East Malaysia.}

The regression analysis was used in this study to identify which of the independent variables (COO image and brand image) has a greater impact towards consumers' purchase intention. Table 3 of the model summary shows that the independent value of $\mathrm{COO}$ image and brand image explains $31.4 \%$ of the variance in the dependent variable of purchase intention based on the adjusted $R$ square value of 0.314 . The other $68.6 \%$ of the model is influenced by other variables that are not investigated in this research.

Table 3.

Model Summary - Effect of COO Image and Brand Image on Purchase Intention

\begin{tabular}{lcccc}
\hline Model & $\boldsymbol{R}$ & $\boldsymbol{R}$ Square Adjusted $\boldsymbol{R}$ & $\begin{array}{c}\text { Standard } \\
\text { Square } \\
\text { Error of the } \\
\text { Estimate }\end{array}$ \\
\hline 1 & 0.565 & 0.320 & 0.314 & 0.541 \\
\hline
\end{tabular}

a. Predictors: Constant, COO Image, Brand Image

Based on Table 4 , the dependent variable (Purchase Intention) is expected to increase by 0.345 if the COO Image increases by 1 and Brand Image is held constant. On the other hand, the variable Purchase Intention is expected to increase by 0.335 if the Brand Image increases by 1 and COO Image are held constant. The results also show that COO Image gives a stronger contribution in explaining the dependent variable $(B=0.345)$ compared to Brand Image $(B=0.335)$ by a small margin. Both the independent variables are making a significant unique contribution towards the prediction of the dependent variable where their significant values are less than $0.05(P<0.05)$. 
Table 4.

Regression Table - Effect of COO Image and Brand Image on Purchase Intention

\begin{tabular}{lccccc}
\hline Model & \multicolumn{2}{c}{ Unstandardized Coefficients } & $\begin{array}{c}\text { Standardized } \\
\text { Coefficients }\end{array}$ & T & Sig. \\
\cline { 2 - 5 } & $B$ & Std. Error & Beta & & \\
\hline (Constant) & 1.199 & 0.248 & & 4.839 & 0.000 \\
COO Image & 0.345 & 0.060 & 0.353 & 5.750 & 0.000 \\
Brand Image & 0.335 & 0.070 & 0.293 & 4.769 & 0.000 \\
\hline
\end{tabular}

a. Dependent Variable: Purchase Intention

Table 5

Model Summary - The Effect of HLPI as Moderator on the Influence of COO Image towards Purchase Intention

\begin{tabular}{lcccc}
\hline Model & $\boldsymbol{R}$ & $\boldsymbol{R}$-Square & Adjusted $\boldsymbol{R}$-Square & Standard Error of the Estimate \\
\hline 1 & 0.508 & 0.258 & 0.252 & 0.565 \\
2 & 0.562 & 0.316 & 0.308 & 0.543 \\
\hline
\end{tabular}

a. Predictors: Constant, High Level of Product Involvement, COO Image

b. Predictors: Constant, High Level of Product Involvement, COO Image, Moderator HLPICOOI

Table 6

Regression Table - The Effect of HLPI as Moderator on the Influence of COO Image towards Purchase Intention

\begin{tabular}{|c|c|c|c|c|c|c|}
\hline \multirow{2}{*}{\multicolumn{2}{|c|}{ Model }} & \multicolumn{2}{|c|}{ Unstandardized Coefficients } & \multirow{2}{*}{$\begin{array}{c}\begin{array}{c}\text { Standardized } \\
\text { Coefficients }\end{array} \\
\text { Beta } \\
\end{array}$} & \multirow[t]{2}{*}{$T$} & \multirow[t]{2}{*}{ Sig. } \\
\hline & & $B$ & Std. Error & & & \\
\hline & (Constant) & 1.901 & 0.241 & & 7.877 & 0.000 \\
\hline & COO Image & 0.503 & 0.065 & 0.515 & 7.785 & 0.000 \\
\hline & High Level of & -0.011 & 0.063 & -0.011 & -0.172 & 0.863 \\
\hline & Product Involvement & & & & & \\
\hline \multirow[t]{5}{*}{2} & (Constant) & 1.432 & 0.253 & & 5.651 & 0.000 \\
\hline & COO Image & 0.519 & 0.062 & 0.532 & 8.346 & 0.000 \\
\hline & High Level of & 0.073 & 0.063 & 0.076 & 1.151 & 0.251 \\
\hline & Product Involvement & & & & & \\
\hline & Moderator HLPICOOI & 0.099 & 0.021 & 0.260 & 4.610 & 0.000 \\
\hline
\end{tabular}

a. Dependent Variable: Purchase Intention

In general terms, the moderator or the high level of product involvement has a significant effect towards the influence of $\mathrm{COO}$ image on purchase intention. This means that the degree of influence on consumers' purchase intention caused by the $\mathrm{COO}$ image depends on the high level of the product involvement. Therefore, this finding supports the study by Shahzad (2014) and Tabassi et al. (2013) where in a high product involvement; purchase decision is highly influenced by $\mathrm{COO}$ information.

\section{Research Objective 4: To identify the effect of high level of product involvement as a moderator in the impact of brand image on East Malaysian consumers' purchase intention.}

The impact of the moderator (high level of product involvement) towards brand image and purchase intention was then tested and the results are shown in Table 7 of the model summary. The analysis shows that the variables of brand image and high level of product involvement explains $24.4 \%$ of the variance of the dependent variable based on the adjusted $R$ square value. However, after the interaction of the moderator was introduced in the Model 2, the value of the adjusted $R$ square increased to 0.271 which means the variables now explain $27.1 \%$ of the variance of the purchase intention variable. The increase in $R$ square value shows that an interaction occurs when moderator was introduced.

Based on Table 8, two models were introduced to explain the interaction that occurs when moderating variables were introduced to the variables. Model 1 shows that the relationship between the variables are significant with $p$ value of less than 0.01 and in Model 2 where the moderator was added into the interaction, there exists a stronger and significant interaction between the variables as the moderator HLPIBI shows a $P$ value of $0.002(P<0.01)$. The result of the analysis shows that the moderator or the high level of product 
Table 7

Model Summary - The Effect of HLPI as Moderator on the Influence of Brand Image Towards Purchase Intention

\begin{tabular}{lcccc}
\hline Model & $\boldsymbol{R}$ & $\boldsymbol{R}$-Square & Adjusted $\boldsymbol{R}$-Square & Standard Error of the Estimate \\
\hline 1 & 0.500 & 0.250 & 0.244 & 0.568 \\
2 & 0.529 & 0.279 & 0.271 & 0.558 \\
\hline
\end{tabular}

a. Predictors: Constant, High Level of Product Involvement, Brand Image

b. Predictors: Constant, High Level of Product Involvement, Brand Image, Moderator HLPIBI

Table 8

Regression Table - The Effect of HLPI as Moderator on the Influence of Brand Image towards Purchase Intention

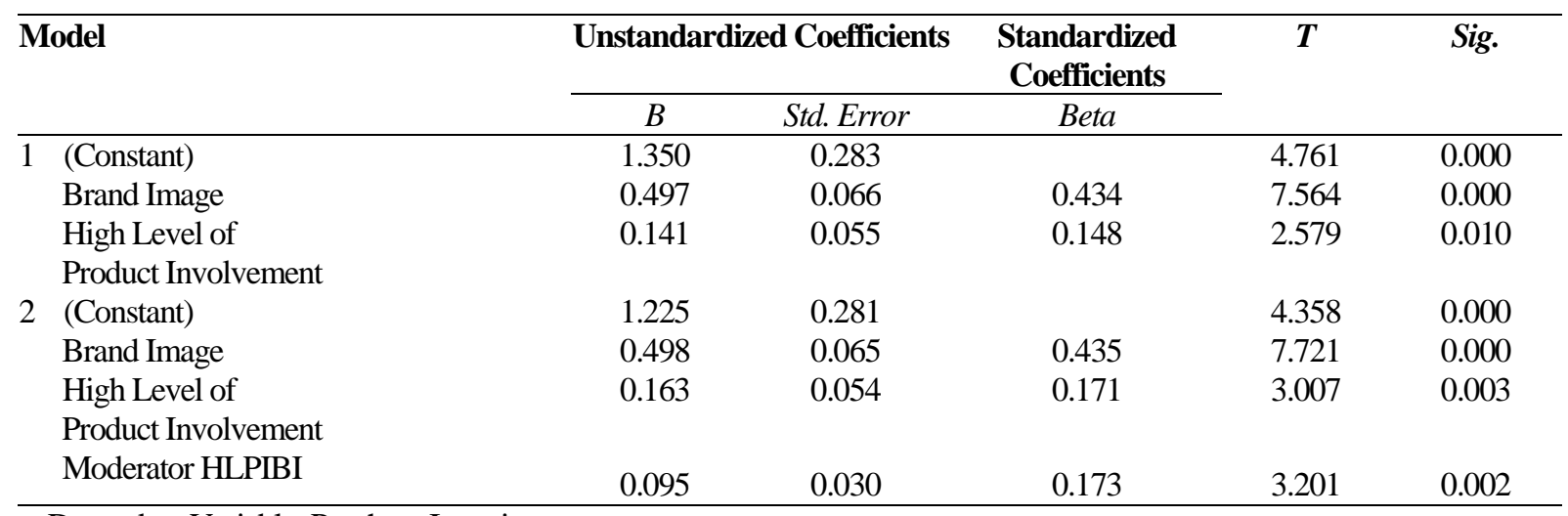

a. Dependent Variable: Purchase Intention

involvement has a significant effect towards the influence of brand image on purchase intention. This means that the degree of influence on consumers' purchase intention caused by the brand image depends on the high level of the product involvement. These results are in line with the study of Zdravkovic (2013) where consumer's involvement is dependent on the social and monetary consequences involved as expensive products would encourage consumers to be more active in searching for the product information and this includes brand image of the product.

Therefore, based on the results obtained from the moderation effect of multiple regression analysis done, it can be concluded that the effects of brand image and $\mathrm{COO}$ image towards consumers' purchase intention depends on high level of product involvement as its moderator. The third objective of the study was achieved, and it is found that the earlier hypothesis made regarding the effect of the moderating variables is accepted.

\section{Conclusion and Implications}

The impact of $\mathrm{COO}$ is important in creating a favourable consumers' perception towards a firm's products and finally, influencing their purchase intention. This study explained the impact of $\mathrm{COO}$ and brand image towards East Malaysian consumers' purchase intention in low and high product involve- ments. The researcher hopes to further help international firms to understand how East Malaysian consumers use the brand and $\mathrm{COO}$ image in their product evaluation. Therefore, by referring to the findings of the study, several recommendations are made for international companies and marketers, to help them leverage their brands that are already in or are planning to enter the Malaysian market.

The findings reveal that East Malaysian consumers put a high importance in country of origin. It is recommended that international firms should try to emphasize their country of origin image which can be done by using their branding and advertising. For example, like what the brand Fiji Natural Artesian Water did that emphasizes the origin of their product. However, the affective processing theory of $\mathrm{COO}$ by Obermiller and Spangenberg (1989) can also be applied for the case of East Malaysian consumers where the effect may vary according to where the brand is from. Firms from a well-known developed country should use $\mathrm{COO}$ information as Malaysian consumer's regards highly of their products. But, firms having a poor $\mathrm{COO}$ image (for example, Chinese products that are viewed as unreliable) should try to obscure them and focus on other cues instead such as brand image to improve their brand perceptions. This would also be the case with firms that have various manufacturing platforms across the world. A firm must be careful in selecting the country where they 
would build their manufacturing plants in. This is due to the effects on $\mathrm{COO}$ where if a firm have a product manufactured in a country that has a negative image it may affect their brand name, especially in Malaysia, where $\mathrm{COO}$ image matters to them. However, if the firm has a strong brand image, then this effect could be ignored as consumers would not be affected by it as was the case with Apple's iPhone.

The results of this research show that East Malaysian consumers put slightly more importance on COO compared to brand image. But, it cannot be denied that brand image would also play an important part in consumers' purchase intention. It is recommended that marketers should focus on emphasizing their brand's strength in their marketing campaigns. The interactions between $\mathrm{COO}$ and brand image that has been identified in this study shows that the concept of 'umbrella brand image' emphasized by Kouba (2008) can be applied with Malaysian consumers too. Thus, it is suggested that international marketers must understand how they can integrate the effects of $\mathrm{COO}$ in brand image on consumer's evaluation towards their product. Emphasizing what their country is good in to their brand image would undoubtedly improve consumer's perceptions towards their brand. For example, the advertisement campaign of "Fueled by Love" by the British Airways in 2016 that shows how caring and affectionate their country is. Finally, the analysis done in this study shows that consumers in East Malaysia place a high importance on $\mathrm{COO}$ and brand image in high involvement products. Thus, it can be concluded that international firms and marketers should focus on working their product's $\mathrm{COO}$ and brand image on expensive products as it gives a larger impact. In terms of cheap products, they should focus more on increasing their brand presence in the market as consumers often purchase these types of products on impulse. The results obtained from this study imply that further researches can be done regarding the topic and other variables that are related. As this study focuses on the high level of product involvement as a moderator, future research can be done in terms of a low level of product involvement as a moderator instead to compare its effect with current research. Previous researches such as Jiménez and San-Martin (2016) show that ethnocentrism has an influence in the effect of $\mathrm{COO}$ and thus, it is suggested that future study can add ethnocentrism as another variable in the effects of $\mathrm{COO}$ image towards East Malaysian consumers' purchase intention. Finally, demographic factors such as age and income levels can also be investigated to identify whether these factors have any effects towards the consumers' $\mathrm{COO}$ perception towards a brand.

\section{References}

Ahmed, Z. U., Johnson, J. P., Ling, C. P., Fang, T. W., \& Hui, A. K. (2002). Country of origin and brand effects on consumers' evaluation of cruise lines. International Marketing Review, 19(3), 279-302.

Ajzen, I. (1991). The theory of planned behaviour. Organizational Behaviour and Human Decision Processes, 50(2), 179-211.

(2005). Attitudes, personality and behaviour. Second Edition. New York: Open University Press.

(2015). The theory of planned behaviour. Retrieved January 3, 2018, from https://www. researchgate.net/figure/Ajzen-theory-of-planned-behavior_fig1_267427600.

Chen, H. (2009). Effects of country variables on young generation's attitude towards American products: A multi-attribute perspective. Journal of Consumer Marketing, 26(3), 143-154.

Department of Statistics Malaysia (2017). Export and import report. Retrieved April 24, 2017, from https://www.dosm.gov.my/v1/\#.

Dodds, W. B., Monroe, K.B., \& Grewal, D. (1991). Effect of price, brand and store information on buyers' product evaluations, Journal of Marketing Research, 28(3), 307-319.

Hanzaee, K. H. \& Khosrozadeh, S. (2011). The effect of the country of origin image, product knowledge and product involvement on information search and purchase intention. Middle-East Journal of Scientific Research, 8(3). 625-636.

Hui, M. K. \& Zhou, L. (2002). Linking product evaluations and purchase intention for country-oforigin effects. Journal of Global Marketing, 15(3-4), 95-116.

Jiménez, N. \& San-Martin, S. (2016). The central role of the reputation of country-of-origin firms in developing markets. Journal of Business \& Industrial Marketing, 31(3), 349-364.

Julian, C. \& Ahmed, Z. (2009). Doing business in Malaysia. Thunderbird International Business Review, 51(1), 53-69.

Keller, K. L. (1993). Conceptualizing, measuring, and managing customer-based brand equity. Journal of Marketing, 57(1), 1-22.

-- (2001). Building customer-based equity: A blueprint for creating strong brands. Research Report. Marketing Science Institute. 01-107.

Kotler, P. (1991). Marketing management: Analysis, planning, implementation, and control. Seventh Edition. English: Prentice-Hall. 
Kouba, Y. (2008). Country of origin, brand image perception, and brand image structure. Asia Pacific Journal of Marketing and Logistics, 20(2), 139-155.

Lai, C., Chiu, C., Yang, C., \& Pai, D. (2010). The effects of corporate social responsibility on brand performance: The mediating effect of industrial brand equity and corporate reputation. Journal of Business Ethics, 95(3), 457469.

Lee, J., James, J., \& Kim, Y. (2014). A reconceptualization of brand image. International Journal of Business Administration, 5(4), 1-11.

Maheswaran, D. (1994). Country of origin as a stereotype: Effects of consumer expertise and attribute strength on product evaluations. Journal of Consumer Research, 21(2), 354-365.

Obermiller, C. \& Spangenberg, E. (1989). Exploring the effects of country-of-origin labels: An information processing framework. Advances in Consumer Research, 16(1), 454-459.

Pallant, J. (2013). SPSS survival manual: A step by step guide to data analysis using IBM SPSS. Fifth Edition. New York: McGraw-Hill.

Pappu, R. Quester, P. G., \& Cooksey, R. W. (2006). Consumer-based brand equity and country-oforigin relationships: Some empirical evidence. European Journal of Marketing, 40(5-6), 696-717.

Saeed, R., Khurshid, N., Safdar, M., Ahmad, W., Lodhi, R.N., \& Ahmad, W. (2013). Countryof-origin effect on Pakistani consumers' evaluation of French cosmetics products. Journal of Basic and Applied Scientific Research, 3(6), 988-1000.

Said, M., Hassan, F., \& Musa, R. (2011). Empirical study on the influence of country-of-origin on consumers' perception towards their purchase intention of Malaysia's Halal food products. In Humanities, Science and Engineering, CHUSER 2011 (pp. 865-870). IEEE, Penang.

Scott, S.L. \& Keith, F.J. (2005). The automatic country of origin effects on brand judgment. Journal of Advertising, 34, 87-98.

Shahzad, A. (2014). The effects of country-of-origin image on consumer product involvement: $A$ Pakistani university teachers' perspective. Manchester: University of Salford.

Shimp, T. A. (2010). Integrated marketing communications in advertising and promotion. Eighth Edition. South-Western: Cengage Learning.

Shimp, T. A., Samie, S., \& Madden, T.J. (1993). Countries and their products: A cognitive structure perspective. Journal of the Academy of Marketing Science, 21(4), 323-330.

Tabassi, S., Esmaeilzadeh, P., \& Sambasivan, M. (2013). The influence of product involvement and country of origin on purchase intention: a study in Malaysia towards European brands. International Journal of Application or Innovation in Engineering and Management, 2(11), 269-277.

Verlegh, P., Steenkamp, J., \& Meulenberg, M. (2005). Country-of-origin effects in consumer processing of advertising claims. International Journal of Research in Marketing, 22(2), 127139.

Zain, O. M. \& Yasin, N. M. (1997). The importance of country-of-origin information and perceived product quality in Uzbekistan. International Journal of Retail \& Distribution Management, 25(4), 138-145.

Zdravkovic, S. (2013). Does country-of-origin matter to generation y? Young Consumers: Insight and Ideas for Responsible Marketers, 14(1), 89-102. 